Sengupta and Parekh: Excellence in Higher Education in India

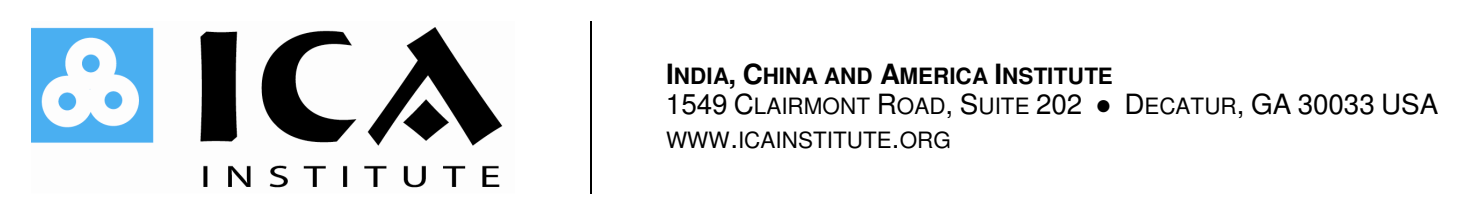

E.reellenes in Higher :education in India: Way forward

A.K. Sen Gupta \& Vikram Parekh

Journal of Emerging Knowledge on Emerging Markets
Volume 1 Issue 1
November 2009 


\section{Excellence in Higher Education in India: Way Forward}

Dr. A.K. Sen Gupta

Director

SIES College of Management Studies, India

Prof. Vikram Parekh

Associate Professor

SIES College of Management Studies, India

Journal of Emerging Knowledge on Emerging Markets

Volume 1 Issue 1

November 2009

\section{Backdrop}

The Indian higher education is at cross roads. There are several reasons for the same.

Notwithstanding the fact that India was one of the first colonial states and therefore one of the few privileged countries to have access to both spoken and written

English, we have possibly lost first mover's advantage because of inadequacy of concerted focus on education by successive governments both at state as well as the centre. Second, educationists and academicians have always been among the most neglected cadres in the country both in terms of monetary compensation as well as recognition. While their global particularly European \& US counterparts draw remuneration almost equal, if not more, than the corporate professionals, salary structure of Indian academic community has been one of the lowest in the country even by standards of public sector. As a result, teaching as a profession, though considered noble, has failed to attract good talent. Finally, though India can take pride in terms of the best professional educational providers by way of IITs and IIMs in global parlance, the general standard of higher education (University higher degree or Ph.D.) needs a substantial facelift as significant mediocrity has crept in the system. This 
is in this background that the present article tries to revisit some of the pending agenda before the higher education in the Indian context.

\section{Education in the Globalized Context}

The higher education in India has not been defined in any document. However, the understanding has been that any education provided after 10+2 level may be construed as such. This is despite that globally there has been some attempt to bring about homogeneity in defining contour of education at various levels. The advent of GATS has expedited the process as there was a need to have uniform understanding of education and to come an understanding to what extent they are covered under provisions of globalization. There has also been considerable debate whether education services come within the purview of GATS. This is because of the Article-I (1.3.b) of WTO that talks about services (for the purpose of inclusion under GATS) mean any services in any sector except services supplied in the exercise of governmental authority. The next sub-section (1.3.c) defines "services supplied in the exercise of governmental authority" as any service which is supplied neither on a commercial basis nor in competition with one or more service suppliers. What it means is that if any services are exclusively provided by the government free of cost or at cost (not for profit) and there are no private players in respect of the said service, they shall be outside the purview of GATS. This is definitely not true for educational services in India and therefore, they definitely come under the jurisdiction of GATS. The informal WTO Classification list (W/120) divides education in five components:
a. Primary education
b. Secondary education
c. Higher education
d. Adult education
e. Other educational services

The proposal submitted by the US to Council for Trade in Services (CTS) in 2000 included two more educational services to be brought under the gamut of GATS. These are:

a. Training services (vocational services), and

b. Testing services (evaluation of students as well as study material for designing and administering tests). 
Though officially there has not been any firm commitment till now by the government of India allowing opening up the sector (under any of the recognized four modes), there is an increasing demand to do so by the world community. This is particularly true for higher education including professional education. The government has already been following Automatic Liberalization (AL) route in respect of some of the sectors. Management education is one example where foreign university entrance rules under Mode-III have already been framed. The UGC document of the $\mathrm{X}^{\text {th }}$ Plan has also acknowledged that scenario for higher education is undergoing dramatic transformation and that Indian higher education providers (particularly the Universities) should equip themselves to withstand pressures of winds of globalization. The recent recommendations of National Knowledge Commission (NKC) also speak about it.

\section{Education in India: Some Facts \& Figures}

Before we analyse the issues relating to how to bring in excellence in higher education, let us have a look at some of the facts and figures relating to education at a glance in India:

Rs 25,000 crores per year are repatriated out of India for Indian students studying abroad. According to the consultation paper, the Asian countries had 3,25,000 students in US colleges and universities in 2004-05, including 80,466 from India, 63,000 from China, 53,000 from South Korea and 42,000 from Japan. Further, 15,000 Indian students were enrolled in the UK, 22,279 in Australia and 2,567 in New Zealand. In 2004, nearly 14 percent of all international students in the US were from India. Education itself generated as much as \$ $\mathbf{1 3 . 4}$ billion in export revenues for US in $\mathbf{2 0 0 3}$. The US has therefore benefited enormously as a result of these revenues, which have come in through Mode 2 (consumption abroad).

1.5 lac Indian students leave the country per year for higher studies. About 4-5 lac students are outside the country at any point of time. The financial impact to families of these students comes to about Rs 50,000 crores per year or US \$ 10 billion per year, enough to build 50 IIMs or 35 IITs per year!

Rs 3,000 crores are spent by nearly 6 lac students trying to arrange and learn for the entrance examination of IITs / IIMs / top business schools in the country. 


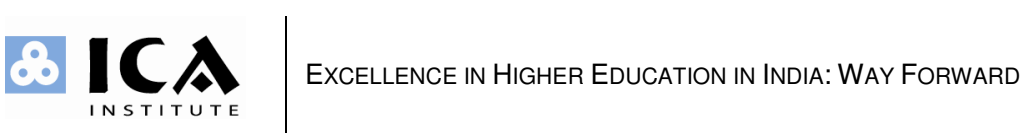

Higher education is subsidized while we still have 350 millions as per GOI who are illiterate.

$>$ The drop out rate between class-I to class $10+2$ is nearly 94 per cent. The present higher education is, therefore, designed only for balance 6 per cent.

$>$ Estimated expenditure in all forms of education for the EU, USA is about $6 \%$ of GDP for primary \& secondary education, 3\% of GDP for VET, 3\% of GDP for R\&D and innovation thus totalling to around $11 \%$ to $12 \%$ of GDP. Total expenditure in India towards education is about $5 \%$ of GDP.

$>$ The present system puts too much emphasis on IQ and not enough on EQ (emotional quotient) and SQ (spiritual quotient).

$>$ We do not seem to be adequately prepared for the open educational system that is likely to emerge in the world in a few years to come.

Source: UGC, Ministry of Higher Education, and $i$ Watch - an NGO promoted by IITians

\section{Student Enrollment \& Public Spending in Higher Education}

The other side of the story is that that there has been phenomenal growth in quantum terms for higher education in India since independence. For example, students' enrolment (formal and non-formal put together) rose from 62.17 lacs in 1992-93 to 1 crore (50 per cent rise) in 2003-2004 (UGC Report). The total enrolment in doctorate and postgraduate level is 65525 and 806636 respectively. It therefore, shows a rather low research base in relation to the total enrolment in higher education. Correspondingly the number of institutions of higher learning has also gone up substantially. The types of higher education during 200506 are as under: 


\section{Table 1: Types of Institutions in Higher Education}

\begin{tabular}{|l|l|}
\hline Type of institutions & $\begin{array}{l}\text { No. of institutions } \\
\text { (As on March 31, 2006) }\end{array}$ \\
\hline Central Universities & 20 \\
\hline State Universities & 217 \\
\hline Deemed Universities & 104 \\
\hline $\begin{array}{l}\text { Institutions (Est. by State } \\
\text { Legislative Act) }\end{array}$ & 5 \\
\hline $\begin{array}{l}\text { Institutions of National } \\
\text { Importance (Est. by Central } \\
\text { Legislation }\end{array}$ & 13 \\
\hline Private Universities & 8 \\
\hline Open Universities & 6 \\
\hline Colleges & 17625 \\
\hline Total & $\mathbf{1 7 , 9 9 8}$ \\
\hline
\end{tabular}

Source: Tenth Plan Profile of Higher Education in India: UGC

Notes:

1. The above does not include several institutions that are outside the purview of the university set-up.

2. The number has gone up substantially during last two years.

If one correlates the increase in student enrolment with increase in public spending in higher education (Table 2), it becomes clear that the increase in public spending has not been commensurate. 


\section{Table 2: Public Expenditure per Student: Nominal and Real (Base year - 1993-94)}

Unit: Rupees

\begin{tabular}{|c|c|c|}
\hline \multirow{2}{*}{ Year } & \multicolumn{2}{|c|}{ Higher Education } \\
\cline { 2 - 3 } & Nominal & Real \\
\hline $1993-94$ & 8961 & 8961 \\
\hline $1994-95$ & 9821 & 8722 \\
\hline $1995-96$ & 9384 & 7717 \\
\hline $1996-97$ & 8438 & 6634 \\
\hline $1997-98$ & 9003 & 6779 \\
\hline $1998-99$ & 10238 & 7276 \\
\hline $1999-00$ & 13219 & 9097 \\
\hline $2000-01$ & 13956 & 8963 \\
\hline $2001-02$ & 12099 & 7501 \\
\hline $2002-03$ & 12294 & 7370 \\
\hline $2003-04$ & 12518 & 7117 \\
\hline
\end{tabular}

Source: working paper on Higher Education, $11^{\text {th }}$ Five year Plan

\section{Quality Perspective}

In context of number of suppliers India is reckoned today a country with one of the largest number of institutions of higher education. However, two most important criteria for higher education to sustain on a long-term basis are accessibility \& global standards in terms of structure and processes. While for the first India still has one of the better credentials, for the second much needs to be done. Herein lies the concerns about achieving excellence in higher education. The issues that need to be looked at greater depth are:

a. Regulation: During the initial phase of development and even today for many areas / sectors, there is no central and single point regulatory authority for the various institutes of higher learning in India. India has seen multiplicity of regulation depending on type of education (AICTE for management education, MCI for 
medical education, and so on). To matter the matter worse, the focus has always been on inputs \& control rather than process or outputs and development. While the entire world has moved from control \& regulation to development \& self regulation, India still stands by the age old model of control-based regulation. Education being a concurrent subject, there has also been some conflict of interest between the state and central governments and this has often given rise to abundant confusion. The recent recommendations of NKC for formation of Independent Regulatory Authority for Higher Education (IRAHE) as the single regulatory body for higher education in India should be viewed in this context. No doubt this will take care of the important issue of multiplicity of regulation; however, this recommendation is not explicit about the type of regulation required for development of institutions of higher learning and therefore, the problem remains as it was.

b. Governance Issues: Institutes of higher learning are expected to be role models of corporate governance including ethical standard, openness and transparency. However, ground reality has been that many of the institutions lack substantially in respect of many of the above areas. These include:

$\begin{array}{ll}\checkmark & \text { Lack of involvement of Governing Council } \\ \checkmark & \text { Absence of Academic Committees } \\ \checkmark & \text { Inadequate student involvement } \\ \checkmark & \text { Insufficient integration with industry \& other stakeholders } \\ \checkmark & \text { Absence of merit-based incentive scheme (including fixed and } \\ \checkmark & \text { variable pay concept) } \\ \checkmark & \text { Lack of process orientation \& quality }\end{array}$

c. Faculty Issues: One of the most important, if not the most critical, cornerstones of any educational set-up is faculty in terms of its adequacy, composition, and quality. The Indian institutes can not be termed to be in a comfortable position in any of the above dimensions. There are no core faculty in many colleges; some have very few and largely depend on outside visiting faculty. Some of these visiting faculty members are not committed ones but simply free-lancers teaching across a large number of institutes without any dedication or focus. Student to faculty ratio is quite adverse (sometimes as high as 20-25:1) compared to international standard / norm of around $8: 1$. Barring a few top institutes / university colleges, majority of the institutes have a very adverse faculty structure in terms of Ph.D. to non - Ph.D. ratio. Against the annual demand of about 10,000 Ph.D.s for teaching staff, India produces hardly 150 doctorates each year. This has resulted in poor quality of teaching process. Further, environment in an institute of higher learning is expected 
to be informal and experiential where faculty is expected to play role of facilitators rather than conventional teachers. Two reasons account for this. First, students in such an environment are expected to learn more through reflection and assimilation of ideas / concepts and application of theory to solving real-life issues than mere understanding of tools and techniques. Second, teachers in such a setting are expected to facilitate process of learning compared to teaching what they intend to. Our personal hypothesis has been that the imperial psychology of "I Centric Approach" is still deep-rooted in Indian scenario including in the educational settings. Therefore, teachers are still considered as deliverers of knowledge from ivory towers of knowledge; there is absence of collegial atmosphere expected in an educational institution; emotional bondage between teachers \& students is virtually non-existent; and above all teachers are seldom considered as mentors, coaches and counselors.

d. Content, Curriculum and Process of Delivery: What is taught in colleges is as important as how it is taught. The importance of content and curriculum in the context of an institute of higher learning can never be underestimated. Three important components of any content and curriculum are quality, relevance and flexibility. While first two are an absolute necessity to ensure quality education, the last one is assuming importance in the emerging world where change has become ultimate reality. Unfortunately in many of the institutes in India, the course content lacks in all above components the way it should be. Scarcity of adequate good faculty affects quality. Curriculum has often been found to be static for as long as a decade and therefore, lost relevance. But the most critical dimension has been that bureaucratic set-up of many institutions has resulted in their devoid of agility to respond to changes in terms of revision and upgrading the curriculum.

Benchmarking with global and comparable institutes and constant internationalization of curriculum and content is an issue that calls for immediate attention in a number of Indian institutions. Besides, there is an urgent need to move away from the traditional approach of teaching in classroom situation to being mentor and facilitator for facilitating the proceedings.

e. Quality related Issues: This has been one of the most serious concerns in higher education. No doubt there has been proliferation but this has possibly accompanied with evil of compromising quality. There have been serious issues of quality in all three parameters namely, inputs, process and output. Majority of them are internal issues. As stated earlier, regulators primarily focus on input aspects and that too quantitative parameters like number of faculty, required quantum of infrastructure, among others. Much less emphasis is laid on ensuring quality issues in processes and resultant quality of final products and their acceptability in market place or in the larger context of community or society at large. The globally prevalent mechanism of enhancing quality through self-regulation and accreditation is possibly the need of hour. 
f. Faculty Development \& Research Issues: The most important criteria for a good institute to become globally competitive on a sustainable basis is creation of "intellectual capital". Apart from providing basic hygiene factors in terms of physical facilities that include residential, computing, and library facilities among others, this also includes creation of an academic ambience suitable for bringing out implicit talent of the faculty. This is more importantly applicable for newly christened faculty. However, barring a few top institutes, unfortunately, even many of the basic hygiene factors are virtually non-existent or grossly inadequate. The classrooms are barely adequate and conducive for learning; there are no provisions for group learning / work; there is no or scarce budget for buying good books; the books that are available are neither the recent ones, nor they do contain latest information. More than sixty per cent of the institutes do not have hostel / residential facility that are imperative not only for extended classroom teaching but also for beyond-classroom socialization process. The computing facilities, particularly the Internet, play a very important role in facilitating the knowledge dissemination. Barring a few institutes that have the facility of 24-hours uninterrupted Internet / Intranet facility, many of the colleges have a very adverse computer to student ratio, as high as 8:1. Lack of adequate research orientation at such an institute is the other critical issue. This is crucial in two ways. Firstly, output of research becomes input for classroom teaching enhancing effectiveness of learning process. And secondly, it provides a good opportunity to students who along with faculty can understand and dissect real life issues. As a result of the above factors, mediocrity among faculty fraternity has become a commonplace phenomenon. This can only result in creation of mediocre outputs by majority of the institutes. The other crucial lacuna in the system is that there is no adequate interaction between institutions and corporate. An analysis of major innovations in the USA in Social Science (more particularly in the management science) reveals that these have come from work by professionals who were involved both in corporate operations as well as attached to academic world. This is not true in Indian scenario. Further, this has also resulted in very limited exposure of faculty of such institutes of higher learning to international seminars \& conferences and resultantly less creation of any new knowledge. The instances of path-breaking researches by Indian faculty are extremely rare.

\section{Future Agenda}

In the earlier paragraphs, the historical perspective as well as both macro \& micro-issues facing institutions of higher learning in the Indian context was deliberated. One of the important conclusions that can be drawn from the discussion is that the post-independent Indian scene has seen proliferation of institutes without commensurate focus on quality. Lack of adequate regulation has definitely a role to play in this regard. Having said so, it must be appreciated that India is a large country with political democracy and any external 
control is always subject to criticism and scrutiny. Therefore, what is needed is to have a free-market determinant that, in course of time, will automatically take care of aberrations and in the end only the better would survive. This free-market phenomenon has already started playing its role in Indian economy in manufacturing and services sector, and soon its impact will be felt in educational field as well. The increasing forces of globalization, WTO agreements related to services (GATS), and impending privatization of Universities in India will only hasten process of growth or atrophy of such institutes depending on their strategy, structure and processes. Accreditation, quality focus, cluster of schools according to market perception of students as well as corporate are the eventualities that loom large and will ultimately differentiate between better managed and other institutions of higher learning.

The strategic choice before the Vice Chancellors / Deans / Directors / principals particularly in the context of a developing nation like India is limited to one or more of the following alternatives:

- To become global on one's own standing (institutions like IITs, IIMs, or BITS, etc.)

- To partner with global Universities / institutes in search of brand name / equity, or

- To maintain one's unique identity but in a niche market (industrial engineering, agriculture, telecommunication, etc.), or

- To become a differentiator in the context of pedagogic approach, innovation, leadership in new frontiers or avenues to maintain a first mover advantage.

But one thing is clear. India has tremendous advantage in terms of substantial qualified manpower, a good number of English knowing population, a large number of middle class / upper middle class residents who believe in philosophy \& relevance of higher education, and a number of world-class providers of higher education. This is in addition to the Eastern philosophy from where a good number of lessons can be drawn. This is totally different from a country like China or Southeast Asian countries where higher education is primarily a western-driven phenomenon. Nevertheless, the market is getting complex, interdependent, and turbulent. New thoughts \& paradigms are emerging with lightning speed. To update, create or disseminate knowledge is increasingly becoming difficult for all streams of higher education. To succeed in this complex world full of diversity and unprecedented global challenges, the prescription for success would be a big challenge and new \& innovative strategies need to be worked out. 